•综述・

\title{
灵长类动物对植物种子的传播作用
}

\author{
陈 远 ${ }^{1}$ 王 征 ${ }^{2}$ 向左甫 ${ }^{*}$ \\ 1 (中南林业科技大学生命科学与技术学院, 长沙 410004) \\ 2 (南京林业大学生物与环境学院，南京 210037)
}

\begin{abstract}
摘要: 种子传播对植物种群空间分布和群落生物多样性维系有着深远的影响。森林灵长类动物可有效地传播植物 种子, 其对果实的选择不仅受其自身形态、生理和行为特征的影响, 也与果实的形态特征和同域分布的其他动物 类群的取食竞争密切相关。灵长类动物传播种子的模式可分为消化道传播、携带传播和颊囊传播，其中消化道传 播距离远、种子萌发或幼苗建成率高, 是最为有效的传播模式。灵长类动物对种子的传播作用还能促进退化生境 的恢复。建议今后研究中应考虑灵长类动物的多途径种子传播和多种因素对种子扩散与萌发的综合影响, 同时要 更加客观地评估灵长类动物缺失对森林植被更新的影响。
\end{abstract}

关键词：灵长类动物；食果过程; 种子传播; 植被更新; 生物多样性保护

\section{Seed dispersal by primates}

\author{
Yuan Chen ${ }^{1}$, Zheng Wang ${ }^{2}$, Zuofu Xiang ${ }^{1 *}$ \\ 1 College of Life Science and Technology, Central South University of Forestry and Technology, Changsha 410004 \\ 2 College of Biology and the Environment, Nanjing Forestry University, Nanjing 210037
}

\begin{abstract}
Seed dispersal facilitates the recruitment of plants, which has profound influences upon the spatial distribution of forest plants and the maintenance of biodiversity. Recently, the role of primates in the process of seed dispersal has been increasingly studied. Primates play an important and special role in plant recruitment and vegetation regeneration in the form of feeding on fruits and dispersing seeds. The selection of different fruits is not only closely related to the quality of fruits and the feeding competition of sympatric animals, but also varies greatly with morphological, physiological, and behavioral features of different primates. According to the processes of fruit treatment, the patterns of seed dispersal by primates can be classified as endozoochory, epizoochory, and synzoochory. These patterns have different effects on the distance of seed dispersal, seed germination, and the establishment of seedlings. The most effective pattern is endozoochory, characterized by long-distance dispersal and high rates of seed germination and seedling establishment. Seed dispersal by many primate species helps to restore degraded habitats. Studies on the ecological processes of seed dispersal by primates and determined factors would be conducive to determine the role of primates in the forest ecological system, the contribution of primates to vegetation regeneration, and to provide theoretical evidence for forest ecosystem management and biodiversity conservation.
\end{abstract}

Key words: primates; frugivory; seed dispersal; vegetation regeneration; biodiversity conservation

在热带雨林中， $50 \%$ 以上的植物果实被食果动 物(以哺乳类和鸟类为主)取食(Howe \& Smallwood, 1982; Levey et al, 2002), 并且60-94\%的木本植物借 助食果动物来实现种子的传播(Arroyo-Rodríguez et $\mathrm{al}, 2015)$ 。啮齿类、翼手类和灵长类是传播种子的
主要的哺乳动物类群(鲁长虎, 2001), 关于前两类动 物的种子传播作用研究历史较长, 而直到最近20年 人们才认识到灵长类动物对植物种子传播的重要 作用(Arroyo-Rodríguez et al, 2015)。栖息于森林中 的灵长类虽然食性广泛多样，但有 $25-40 \%$ 的种类

收稿日期: 2016-06-02; 接受日期: 2017-01-11

基金项目: 国家科技支撑计划(2013BAD03-02)、国家自然科学基金(31670397)和国家林业局野生动物保护与繁育项目

* 通讯作者 Author for correspondence. E-mail: xiangzf@csuft.edu.cn 
取食植物果实, 排出或吐出大量具有萌发能力的种 子(Lambert, 1999), 对森林植被的更新和生物多样 性的维系起着至关重要的作用(Cain et al, 2000; Wang \& Smith, 2002)。迄今为止, 很多学者以狐猴 科(Dew \& Wright, 1998)、卷尾猴科(Wehncke \& Dominguez, 2007)、僧面猴科(Barnett et al, 2012)、 蜘蛛猴科(Bicca-Marques, 2003)、狘科(Cardoso et al, 2011)、猴科(Albert et al, 2013)、长臂猿科(范朋飞等, 2008)和猩猩科(Petre et al, 2015)等灵长类动物为研 究对象, 对它们的食果过程、传播种子数量、传播 距离和种子萌发率等方面进行了比较详细的研究。

灵长类动物传播种子的过程较为复杂, 涉及到 它们的食性、种子传播模式、传播距离、对种子萌 发和幼苗建成的影响等多个层面(Schupp et al, 2010)。作为森林中典型的大型食果动物, 了解灵长 类动物种子传播的生态过程, 不仅有助于探讨森林 生态系统中动植物间的相互关系及其生态意义, 还 可进一步明确灵长类动物对森林植被更新的贡献。

\section{1 影响灵长类动物取食和传播果实的因素}

灵长类动物的食性范围广泛, 不同种类取食的 植物种类和数量也存在较大差异。而它们多样的取 食行为和活动模式形成了较复杂的果实处理过程。 一般来说, 影响灵长类取食和传播果实或者种子的 因素主要有以下3点:

(1) 灵长类动物的个体特征, 如形态特征(口腔 和肠道特点)、生理特征(食物消化时间)和行为习惯 等因素, 均影响它们取食和传播植物的果实和种 子。许多灵长类动物有着较长的消化道, 食物滞留 时间(gut retention time)较长(Maisels, 1993), 往往能 取食大量的种子(Rudran, 1978), 但其口腔大小、牙 齿形态以及肠道形态结构都会影响它们吞咽的种 子大小与种类。如, 南美洲的白面僧面猴(Pithecia pithecia)和红背僧面猴属(Chiropotes)动物因具有高 度特化的牙齿, 能够取食具有硬质外壳的大型果实 (Norconk et al, 2011)。动物的取食行为, 如取食果肉 后是将种子吞下还是丢弃, 也会影响果实(种子)的 传播(Lambert, 1998)。例如, 在厄瓜多尔亚松国家公 园, 白额蜘蛛猴(Ateles belzebuth)至少取食152种植 物的果实, 它们将绝大多数种子 (98\%)整体吞下, 其中毁坏的种子仅占极少数(Link \& Fiore, 2006); 在中国云南的无量山, 黑长臂猿 (Nomascus concolor)取食31种植物果实, 并为27种肉质果植物 传播种子(范朋飞等, 2008)。

(2) 植物果实的丰富度或分布模式、果实和种 子的硬度、大小、颜色和形态以及所具有的营养成 分均能影响灵长类动物对果实的选择 (Leighton, 1993; Russo \& Chapman, 2011; 阮海河等, 2013)。栖 息地果实数量多且成熟期持续时间长, 灵长类动物 就会多次在该树采食, 对植物种子的搬运频次和数 量也会增多(Agetsuma \& Noma, 1995; Garber \& Paciulli, 1997)。Sengupta和Radhakrishna (2015)发现, 猕猴(Macaca mulatta) 更喜欢取食具有壳状外皮、多 汁而柔软的果肉, 以及具有中大型种子和坚硬种皮 的大型果实; 阮海河等(2013)也发现, 在越南的广 平风芽-格邦国家自然公园, 河静黑叶猴 (Trachypithecus francoisi hatinhensis)对处理难度较 小的浆果和核果有着明显的偏好, 并且更多地选择 黄色、红色和绿色的果实。

(3) 灵长类动物的受食对策也受到同域生活的 其他动物类群的竞争影响。如, McConkey等(2002) 在印度尼西亚的加里曼丹岛发现, 灰长臂猿 (Hylobates muelleri)和黑掌长臂猿(H. agilis)的果实 选择受到了其他灵长类动物(猩猩和狝猴)的竞争影 响。一般而言, 植物果实被森林中所有食果动物共 同取食, 食性广泛的动物相对于食性较窄的动物更 容易获取果实和传播种子 (Sengupta \& Radhakrishna, 2015)。

\section{2 灵长类动物的种子传播作用}

\section{1 种子传播模式}

灵长类动物对种子的传播模式可分为 3 种: 消 化道传播(endozoochory)、携带传播(epizoochory)和 项囊传播(synzoochory) (Kaplin \& Moermond, 1998; Albert et al, 2013)。

(1) 消化道传播模式, 即吞咽后排出种子。这是 灵长类动物最主要的传播模式(Russo \& Chapman, 2011)。如, 在非洲刚果的萨隆加国家公园, 倭黑猩 猩(Pan paniscus)所传播的植物种子中, $93 \%$ 以上是 经消化道传播(Beaune et al, 2013); 在南美洲新热带 区, 消化道传播亦是最为常见的灵长类动物的种子 传播模式(Estrada \& Coates-Estrada, 1984; Chapman, 1989; Andresen, 1999), 该模式无论从种子传播的距 离或是对种子的萌发都起着积极作用 (Lambert, 
2002; Russo \& Chapman, 2011)。

(2) 携带传播模式, 即取食果肉后丢弃种子。这 种模式在灵长类动物种子传播中不太常见。一般的 途径是灵长类动物取食果肉后直接丢弃或吐出种子, 有些甚至是将未吃完的果实整个丢弃。Koné等(2008) 研究发现, 非洲西部国家公园的几种猴科灵长类动 物能将果实带离母树一段距离, 它们常在打开果实 时丢弃种子或把肉质的浆果取食后吐出种子。

(3) 颊囊传播模式, 即㚘異处理后吐出种子。仅 见于具有颊囊的猕猴属 (Macaca) 和长尾猴属 (Cercopithecus) 灵长类动物 (Albert et al, 2013; Linden et al, 2015)。它们在取食时先将果实塞满项 囊并暂时储存, 在母树以外的地点处理完果实后吐 出种子, 进而起到传播种子的作用(Corlett \& Lucas, 1990), 部分吞下的种子则可认为是经消化道传播。 狝猴属动物通过使用项囊, 能传播体积较大且数量 多的种子, 而它们较大的活动范围则促进了种子的 长距离传播(Albert et al, 2014)。

\section{2 种子传播距离}

与其他动物类群相比, 灵长类动物活动于森林 的各个林层(Albert et al, 2013), 因此使得传播的种 子在空间分布上更为广泛。不同的传播模式对种子 传播的距离差异很大: 携带传播模式传播的距离通 常仅有几米, 造成种子大量聚集在母树周围, 资源 竞争等因素使种子死亡率大幅度上升(Janzen, 1970; Connell, 1971)。消化道传播模式却能将种子带到离 母树数百米甚至数千米的适宜生境而提高了种子 的存活率(Russo \& Chapman, 2011)。规亭传播模式 中, 狝猴属动物虽然有特殊项囊进行种子传播, 但 其粪便内的种子平均传播距离(116.5 m) 远长于口腔 吐出种子的距离 $(19.2 \mathrm{~m})$, 并且猕猴属动物吐出的 种子有39\%是在取食树种的树冠下发现的, 而粪便 中传播的种子通常都远离母树树冠(Sengupta et al, 2014)。

种子的传播距离还受其他一些因素影响。如, 在消化道传播模式中, 灵长类动物的日间移动模式 和消化道滞留时间均会影响种子的传播距离。许多 灵长类动物多年栖息在同一地点(如休息场所和夜 宿地) (Chapman, 1989; Julliot, 1997), 导致这些地点 的种子排放率很高而未进行有效传播 (Russo \& Chapman, 2011)。一些体型较大的灵长类动物通常 每天能进行长距离移动(Carbone et al, 2005), 种子
传播距离也因其较长的消化道滞留时间而潜在增 长(Petre et al, 2015)。如, 在巴西片断化森林中体型 较大的吼猴属(Alouatta)动物具有较长的日间活动 距离, 能将种子传播至距离母树 $497 \mathrm{~m}$ 远的地方 (Bicca-Marques, 2003); 少数大型猿类对种子的传 播距离有时甚至超过1,000 m (Tsuji et al, 2010; Beaune et al, 2013)。此外, 摄取种子的时间也会影 响种子的传播距离, 例如, 安第斯线毛猴 (Lagotherix lagothricha)对上午取食种子的传播距 离更远(Stevenson et al, 2014)。

种子的传播距离对其后期萌发及扩散有着重 要的影响, 长距离传播有助于提高植物更新的可能 性, 对于植物种群的扩张、小种群的维系、定殖和 基因流动有着重要意义(Schupp et al, 2010)。一般而 言, 距离母树 $5 \mathrm{~m}$ 远的种子存活率明显高于母树树 冠下的种子(Chapman \& Chapman, 1995), 但只有被 传播至距离母树超过 $100 \mathrm{~m}$ 远的地方, 才认为是最 为有效的种子传播方式(Cain et al, 2000; Schupp et al, 2010)。因此, 尽管灵长类动物对植物种子的传播 距离因传播模式各异, 但仅消化道传播属于长距离 传播, 才是维系植物动态、促进种群扩张和基因流 动的关键的传播模式。

\section{3 传播对种子萌发和幼苗建成的影响}

灵长类动物取食果实不仅能将种子带到适宜 萌发的微环境, 减少种子萌发时植物种间的竞争和 被捕食者捕食的危险(Andresen, 1999), 更重要的是 在传播过程中, 种子经过动物的处理而改变了其萌 发特性和幼苗的建成能力(Arroyo-Rodríguez et al, 2015)。已有研究表明灵长类动物的传播作用促进了 植物种子的萌发, 对幼苗的生长有着积极作用 (Stevenson et al, 2002; Righini et al, 2004; Beaune et al, 2013)。

消化道传播可以提高种子的萌发率，缩短种子 萌发所需的时间(Traveset, 1998), 主要原因是: (1) 动物消化道对内果皮和种皮进行的化学或机械性 摩擦产生了“破皮”作用，促进了种子的萌发 (Traveset \& Verdú, 2002); (2)种子外的果肉能抑制种 子的萌发或促进病原体的生长(Traveset et al, 2007), 灵长类动物将它们移除起到了 “解除抑制”的作用; (3) 灵长类动物粪便中所含的营养物质具有施肥效 应(Robertson et al, 2006)。如, 在委内瑞拉古里水库 的陆桥岛屿上, 红吼猴(Alouatta seniculus)粪便的密 
集堆积能够丰富土壤中氮、磷等营养物质, 促进幼 苗的建成(Feeley, 2004)。此外, Arroyo-Rodríguez等 (2015)发现, 吼猴属灵长类的消化道对植物种子生 存和萌发的另一个积极作用是控制了果实或种子 中昆虫幼虫的发生。

但也有研究发现, 灵长类动物通过对果实(种 子)的取食给种子的萌发带来了负作用(Estrada \& Coates-Estrada, 1984; Poulsen et al, 2001; Stevenson et $\mathrm{al}, 2002)$ 。主要原因是灵长类动物在取食过程中容易 将种子的种皮一并嚼碎(Hemingway, 1996), 一些小 型的种子经消化道处理后很难存活下来(Dew \& Wright, 1998; Mourthé et al, 2008)。另外, 体型较大的 灵长类动物粪堆中聚集着较多的种子 (Chapman, 1989; González-Zamora et al, 2014), 这可能引起病原 体感染或增加被取食(如啮齿类等)的概率(Howe \& Smallwood, 1982), 使种子的存活率降低。

\section{3 灵长类动物与森林植物的关系}

灵长类动物通过取食植物果实, 将种子带离母 树, 直至种子萌发和幼苗建成, 形成完整而有效的 传播途径。在长期的进化过程中, 灵长类动物和食 源植物间已经形成了广泛的互利或互惠关系, 它们 之间的协同进化是一种动态平衡状态(Lord et al, 2002; Fleming \& Kress, 2011)。研究表明, 食果动物 对种子的传播在热带生态系统中是一种普遍存在 的现象, 果食性猴科灵长类的食物至少包含 $80 \%$ 的 果实, 促进了 75\%的种子萌发(Fuzessy et al, 2016)。 在木本植物中, 有50-90\%的物种被食果性脊椎动 物取食, 并且大部分树种的果实出现了明显利于动 物传播的形态特征 (Howe \& Smallwood, 1982; Janson, 1983; Tabarelli \& Peres, 2002)。

灵长类动物对种子的传播不仅对于森林植物 的空间分布和植物多样性维系有着重要的影响, 而 且在种子传播网络中所扮演的角色往往是关键性 的。如, 在刚果萨隆加国家公园, 尽管在无动物传 播和风力散播的作用下有种子排放, 但许多植物物 种因缺少倭黑猩猩而无法在果实掉落区域实现自 我更新并充分地进行种群扩张(Beaune, 2015); 同 样, 在新热带区森林中蜘蛛猴科灵长类的丰度和植 物幼苗的多样性表现出正相关关系 (Stevenson, 2011)。

灵长类动物对森林植被的恢复起到积极作用
(Russo \& Chapman, 2011), 例如, 大多数非灵长类食 果动物不能使用隔离或者空旷的栖息地(Albert et al, 2013), 而狝猴属动物却能够穿越各种类型的森林, 这种游走式的活动格局为退化生境的修复提供了帮 助; 吼猴属动物有助于森林的次级演替, 能促进退 化栖息地的恢复(Arroyo-Rodríguez et al, 2015)。

\section{4 灵长类动物传播种子的生态学意义}

灵长类动物是热带和亚热带地区食果脊椎动 物的重要组成部分, 对植物果实的取食和种子传播 产生了巨大的影响(Garber \& Lambert, 1998)。许多 研究表明, 灵长类动物之所以成为重要的植物种子 传播者, 主要是因为植物种子经动物消化道排出后 仍保持着良好的萌发能力(Stevenson et al, 2002; Righini et al, 2004; Sengupta et al, 2014)。很显然, 食 果性的灵长类动物通过对植物果实和种子的取食, 对种子传播产生了积极影响(Fuzessy et al, 2016), 灵长类动物对种子的传播不但影响了植物从种子 到幼苗期的存活状态 (Janzen, 1970; McCanny, 1985), 最终还影响植物在群落中的空间分布格局 (Nathan \& Muller-Landau, 2000; Wang \& Smith, 2002)。更为重要的是, 灵长类动物的种子传播对于 许多热带树种的定殖起着关键作用, 这对维持植物 种群的多样性有着重要意义(Howe \& Smallwood, 1982; Julliot, 1997; Link \& Fiore, 2006)。

灵长类动物在森林生态系统中扮演着独特的 生态角色。与其他传播动物类群相比, 灵长类动物 体型多样、活动范围大且具有复杂的取食行为等特 点(Stevenson et al, 2002; Martins, 2006; Bravo, 2009), 这些特点为种子提供的传播途径较为独特, 并且这些传播方式(如种子传播距离等)通常是植物 生长环境中其他动物传播者无法替代的(Tutin et al, 1991; Otani, 2010; Bueno et al, 2013)。一般来说, 成 熟的大型植物果实无法由食果鸟类、果蝠类和某些 食果性树栖哺乳动物(如蜜熊Potos flavus)打开或吞 下后带离母树进行传播(Hallwachs, 1986; Link \& Fiore, 2006)。虽然掉落至地面的某些大型果实或种 子可经咜藏性啮齿动物的分散它食 (scatter-hoarding)而传播, 但这对于种子传播的作用 甚微, 只有通过灵长类动物的取食才能大幅度地改 变此类种子扩散的模式(Tutin et al, 1991; Jansen et al, 2002; Otani, 2010)。如, 在哥伦比亚奎瓦国家公 
园, 几种果实具有外皮包被的植物种子, 仅通过安 第斯线毛猴进行传播(Stevenson et al, 2014); 较小 型的传播者, 如鸟类、啮齿类和果蝠类虽能传播一 些植物种子, 但因果实处理过程、种子传播数量和 种子排放生境的差异等而不能产生与倭黑猩猩相 似的传播效果(Beaune, 2015)。

\section{5 研究展望}

我国关于灵长类动物与植物种子传播的关系 研究起步较晚, 尚有大量的工作需要开展。目前, 灵长类动物种子传播过程的研究多在于独立探究 单方面的传播途径, 但种子传播的过程是多途径同 时进行的, 甚至传播后期种子萌发也受多种因素影 响。为进一步理解灵长类动物在森林生态系统中的 地位, 以及加强生物多样性保护、森林生态系统管 理, 仍需要深入开展如下相关研究:

(1) 综合考虑灵长类动物的多途径种子传播。 由于灵长类动物特殊的取食行为, 传播种子时往往 是几种模式同时进行, 还可能具有一定的互补性。 若将多种传播模式结合起来分析, 并加以模型化, 能更充分地理解灵长类动物在森林生态系统中所 扮演的角色。

(2) 充分考虑多种因素对种子扩散与萌发的影 响。在灵长类动物传播种子后, 地面的种子还会受 到森林中其他动物(如鸟类、啮齿类)的二次传播, 也 可能受到蜕螂(Onthophagus spp.)等昆虫的捕食, 这 些因素也会影响种子传播的有效性, 未来应该加强 这方面的研究。

(3) 客观评估灵长类动物缺失对森林植被更新 的影响。近年来, 生境破坏等因素使灵长类动物种 群数量减少, 这无疑将改变动植物系统的稳定性, 进而给植物的更新带来消极影响(Stevenson, 2011)。 在开展灵长类动物种子传播研究的同时, 更应该客 观评估灵长类对森林植被更新的影响。

致谢: 陈浩春、张波、郭程、卢浪、魏博彦等在论 文初稿形成过程中给予了有益的帮助; 两位审稿专 家对论文的初稿提出了宝贵意见和建议, 在此一并 致谢。

\section{参考文献}

Agetsuma N, Noma N (1995) Rapid shifting of foraging pattern by Yakushima macaques (Macaca fuscata yakui) in re- sponse to heavy fruiting of Myrica rubra. International Journal of Primatology, 16, 247-260.

Albert A, Savini T, Huynen MC (2013) The role of Macaca spp. (Primates: Cercopithecidae) in seed dispersal networks. The Raffles Bulletin of Zoology, 61, 423-434.

Albert A, McConkey K, Savini T, Huynen MC (2014) The value of disturbance-tolerant cercopithecine monkeys as seed dispersers in degraded habitats. Biological Conservation, 170, 300-310.

Andresen E (1999) Seed dispersal by monkeys and the fate of dispersed seeds in a Peruvian rain forest. Biotropica, 31, 145-158.

Arroyo-Rodríguez V, Andresen E, Bravo SP, Stevenson PR (2015) Seed dispersal by howler monkeys: current knowledge, conservation implications, and future directions. In: Howler Monkeys (eds Kowalewski MM, Garber PA, Cortés-Ortiz L, Urbani B, Youlatos D), pp. 111-139. Springer, New York.

Barnett AA, Boyle SA, Pinto LP, Lourenço WC, Almeida T, Silva WS, Ronchi-Teles B, Bezerra BM, Ross C, Maclarnon A, Spironello WR (2012) Primary seed dispersal by three neotropical seed-predating primates (Cacajao melanocephalus ouakary, Chiropotes chiropotes and Chiropotes albinasus). Journal of Tropical Ecology, 28, 543-555.

Beaune D, Bretagnolle F, Bollache L, Bourson C, Hohmann G, Fruth B (2013) Ecological services performed by the bonobo (Pan paniscus): seed dispersal effectiveness in tropical forest. Journal of Tropical Ecology, 29, 367-380.

Beaune D (2015) What would happen to the trees and lianas if apes disappeared? Oryx, 49, 442-446.

Bicca-Marques JC (2003) How do howler monkeys cope with habitat fragmentation? In: Primates in Fragments: Ecology and Conservation (ed. Marsh LK), pp. 283-303. Springer, New Mexico.

Bravo SP (2009) Implications of behavior and gut passage for seed dispersal quality: the case of black and gold howler monkeys. Biotropica, 41, 751-758.

Bueno RS, Guevara R, Ribeiro MC, Culot L, Bufalo FS, Galetti M (2013) Functional redundancy and complementarities of seed dispersal by the last neotropical megafrugivores. PLoS ONE, 8, e56252.

Cain ML, Milligan BG, Strand AE (2000) Long-distance seed dispersal in plant populations. American Journal of Botany, 87, 1217-1227.

Carbone C, Cowlishaw G, Isaac NJB, Rowcliffe JM (2005) How far do animals go? Determinants of day range in mammals. The American Naturalist, 165, 290-297.

Cardoso NA, Pendu YL, Lapenta MJ, Raboy BE (2011) Frugivory patterns and seed dispersal by golden-headed lion tamarins (Leontopithecus chrysomelas) in Una Biological Reserve, Bahia, Brazil. Mammalia, 75, 327-337.

Chapman CA (1989) Primate seed dispersal: the fate of dispersed seeds. Biotropica, 21, 148-154.

Chapman CA, Chapman LJ (1995) Survival without dispersers: seedling recruitment under parents. Conservation Biology, 9, 675-678. 
Connell JH (1971) On the role of natural enemies in preventing competitive exclusion in some marine animals and in rain forest trees. Dynamics of Populations, 298, 298-312.

Corlett RT, Lucas PW (1990) Alternative seed-handling strategies in primates: seed-spitting by long-tailed macaques (Macaca fascicularis). Oecologia, 82, 166-171.

Dew JL, Wright P (1998) Frugivory and seed dispersal by four species of primates in Madagascar's eastern rain forest. Biotropica, 30, 425-437.

Estrada A, Coates-Estrada R (1984) Fruit eating and seed dispersal by howling monkeys (Alouatta palliata) in the tropical rain forest of Los Tuxtlas, Mexico. American Journal of Primatology, 6, 77-91.

Fan PF, Huang B, Jiang XL (2008) Seed dispersal by black gibbons (Nomascus concolor) in the Wuliang Mountains, Central Yunnan. Acta Theriologica Sinica, 28, 232-236. (in Chinese with English abstract) [范朋飞, 黄蓓, 蒋学龙 (2008) 云南无量山黑长臂猿对植物种子的传播作用. 兽 类学报, 28, 232-236.]

Feeley K (2004) The role of clumped defecation in the spatial distribution of soil nutrients and the availability of nutrients for plant uptake. Journal of Tropical Ecology, 20, 1-4.

Fleming TH, Kress WJ (2011) A brief history of fruits and frugivores. Acta Oecologica, 37, 521-530.

Fuzessy LF, Cornelissen TG, Janson C, Silveira FAO (2016) How do primates affect seed germination? A meta-analysis of gut passage effects on neotropical plants. Oikos, 125, 1069-1080.

Garber PA, Paciulli LM (1997) Experimental field study of spatial memory and learning in wild capuchin monkeys (Cebus capucinus). Folia Primatologica, 68, 236-253.

Garber PA, Lambert JE (1998) Primates as seed dispersers: ecological processes and directions for future research. American Journal of Primatology, 45, 3-8.

González-Zamora A, Arroyo-Rodríguez V, Escobar F, Rős M, Oyama K, Ibarra-Manríquez G, Stoner KE, Chapman CA (2014) Contagious deposition of seeds in spider monkeys' sleeping trees limits effective seed dispersal in fragmented landscapes. PLoS ONE, 9, e89346.

Hallwachs W (1986) Agoutis (Dasyprocta punctata): the inheritors of guapinol (Hymenaea courbaril: Leguminosae). In: Frugivores and Seed Dispersal (eds Estrada A, Theodore H), pp. 285-304. Springer, Dordrecht.

Hemingway CA (1996) Morphology and phenology of seeds and whole fruit eaten by Milne-Edwards' sifaka, Propithecus diadema edwardsi, in Ranomafana National Park, Madagascar. International Journal of Primatology, 17, 637659.

Howe HF, Smallwood J (1982) Ecology of seed dispersal. Annual Review of Ecology and Systematics, 13, 201-228.

Jansen PA, Bartholomeus M, Bongers F, Elzinga JA, Ouden JD, Wieren SEV (2002) The role of seed size in dispersal by a scatter-hoarding rodent. In: Seed Dispersal and Frugivory: Ecology, Evolution and Conservation (eds Levey DJ, Silva WR, Galetti M), pp. 209-225. CABI Publishing, Walling- ford.

Janson CH (1983) Adaptation of fruit morphology to dispersal agents in a neotropical forest. Science, 219, 187-189.

Janzen DH (1970) Herbivores and the number of tree species in tropical forests. The American Naturalist, 104, 501-528.

Julliot C (1997) Impact of seed dispersal by red howler monkeys Alouatta seniculus on the seedling population in the understorey of tropical rain forest. Journal of Ecology, 85, 431-440.

Kaplin BA, Moermond TC (1998) Variation in seed handling by two species of forest monkeys in Rwanda. American Journal of Primatology, 45, 83-101.

Koné I, Lambert JE, Refisch J, Bakayoko A (2008) Primate seed dispersal and its potential role in maintaining useful tree species in the Taï region, Côte-d'Ivoire: implications for the conservation of forest fragments. Tropical Conservation Science, 1, 293-306.

Lambert JE (1998) Primate digestion: interactions among anatomy, physiology, and feeding ecology. Evolutionary Anthropology: Issues, News, and Reviews, 7, 8-20.

Lambert JE (1999) Seed handling in chimpanzees (Pan troglodytes) and redtail monkeys (Cercopithecus ascanius): implications for understanding hominoid and cercopithecine fruit-processing strategies and seed dispersal. American Journal of Physical Anthropology, 109, 365-386.

Lambert JE (2002) Exploring the link between animal frugivory and plant strategies: the case of primate fruit processing and post-dispersal seed fate. In: Seed Dispersal and Frugivory: Ecology, Evolution and Conservation (eds Levey DJ, Silva WR, Galetti M), pp. 365-379. CABI Publishing, Wallingford.

Leighton M (1993) Modeling dietary selectivity by Bornean orangutans: evidence for integration of multiple criteria in fruit selection. International Journal of Primatology, 14, 257-313.

Levey DJ, Silva WR, Galetti M (2002) Seed Dispersal and Frugivory: Ecology, Evolution and Conservation. CABI Publishing, Wallingford.

Linden B, Linden J, Fischer F, Linsenmair KE (2015) Seed dispersal by South Africa's only forest-dwelling guenon, the samango monkey (Cercopithecus mitis). South African Journal of Wildlife Research, 45, 88-99.

Link A, Fiore AD (2006) Seed dispersal by spider monkeys and its importance in the maintenance of neotropical rain-forest diversity. Journal of Tropical Ecology, 22, 235-246.

Lord JM, Markey AS, Marshall J (2002) Have frugivores influenced the evolution of fruit traits in New Zealand. In: Seed Dispersal and Frugivory: Ecology, Evolution and Conservation (eds Levey DJ, Silva WR, Galetti M), pp. 55-68. CABI Publishing, Wallingford.

$\mathrm{Lu} \mathrm{CH}$ (2001) Effect of rodents on seed dispersal. Chinese Journal of Ecology, 20, 56-58. (in Chinese with English abstract) [鲁长虎 (2001) 啮齿类对植物种子的传播作用. 生态学杂志, 20, 56-58.]

Maisels F (1993) Gut passage rate in guenons and mangabeys: 
another indicator of a flexible feeding niche? Folia Primatologica, 61, 35-37.

Martins MM (2006) Comparative seed dispersal effectiveness of sympatric Alouatta guariba and Brachyteles arachnoides in southeastern Brazil. Biotropica, 38, 57-63.

McCanny SJ (1985) Alternatives in parent-offspring relationships in plants. Oikos, 45, 148-149.

McConkey KR, Aldy F, Ario A, Chivers DJ (2002) Selection of fruit by gibbons (Hylobates muelleri $\times$ agilis) in the rain forests of central Borneo. International Journal of Primatology, 23, 123-145.

Mourthé ÍMC, Strier KB, Boubli JP (2008) Seed predation of Mabea fistulifera (Euphorbiaceae) by northern muriquis (Brachyteles hypoxanthus). Neotropical Primates, 15, 40-45.

Nathan R, Muller-Landau HC (2000) Spatial patterns of seed dispersal, their determinants and consequences for recruitment. Trends in Ecology and Evolution, 15, 278-285.

Nguyen HH, Bai B, Li N, Pan Y, Lu CH (2013) Fruit diet, selectivity and seed dispersal of Hatinh langur (Trachypithecus francoisi hatinhensis). Acta Ecologica Sinica, 33, 110-119. (in Chinese with English abstract) [阮海河, 白冰, 李宁, 潘扬, 鲁长虎 (2013) 河静黑叶猴果实性食物组 成、选择及其对种子的扩散作用. 生态学报, 33, 110-119.]

Norconk MA, Veres M (2011) Physical properties of fruit and seeds ingested by primate seed predators with emphasis on sakis and bearded sakis. The Anatomical Record, 294, 2092-2111.

Otani T (2010) Seed dispersal by Japanese macaques. In: The Japanese Macaques (eds Nakagawa N, Nakamichi M, Sugiura H), pp. 129-142. Springer, Tokyo.

Petre CA, Tagg N, Beudels-Jamar RC, Haurez B, Doucet JL (2015) Western lowland gorilla seed dispersal: are seeds adapted to long gut retention times? Acta Oecologica, 67, 59-65.

Poulsen JR, Clark CJ, Smith TB (2001) Seed dispersal by a diurnal primate community in the Dja Reserve, Cameroon. Journal of Tropical Ecology, 17, 787-808.

Righini N, Serio-Silva JC, Rico-Gray V, Martínez-Mota R (2004) Effect of different primate species on germination of Ficus (Urostigma) seeds. Zoo Biology, 23, 273-278.

Robertson AW, Trass A, Ladley JJ, Kelly D (2006) Assessing the benefits of frugivory for seed germination: the importance of the deinhibition effect. Functional Ecology, 20, 58-66.

Rudran R (1978) Socioecology of the blue monkeys (Cercopithecus mitis stuhlmanni) of the Kibale forest, Uganda. Smithsonian Institution Press, Washington DC.

Russo SE, Chapman CA (2011) Primate seed dispersal: linking behavioral ecology with forest community structure. Primates in Perspective, 2, 523-534.

Schupp EW, Jordano P, Gómez JM (2010) Seed dispersal effectiveness revisited: a conceptual review. New Phytologist,
188, 333-353.

Sengupta A, McConkey KR, Radhakrishna S (2014) Seed dispersal by rhesus macaques Macaca mulatta in northern India. American Journal of Primatology, 76, 1175-1184.

Sengupta A, Radhakrishna S (2015) Fruit trait preference in rhesus macaques (Macaca mulatta) and its implications for seed dispersal. International Journal of Primatology, 36, 999-1013.

Stevenson PR, Castellanos MC, Pizarro JC, Garavito M (2002) Effects of seed dispersal by three ateline monkey species on seed germination at Tinigua National Park, Colombia. International Journal of Primatology, 23, 1187-1204.

Stevenson PR (2011) The abundance of large ateline monkeys is positively associated with the diversity of plants regenerating in neotropical forests. Biotropica, 43, 512-519.

Stevenson PR, Link A, Onshuus A, Quiroz AJ, Velasco M (2014) Estimation of seed shadows generated by Andean woolly monkeys (Lagothrix lagothricha lugens). International Journal of Primatology, 35, 1021-1036.

Tabarelli M, Peres CA (2002) Abiotic and vertebrate seed dispersal in the Brazilian Atlantic forest: implications for forest regeneration. Biological Conservation, 106, 165-176.

Traveset A (1998) Effect of seed passage through vertebrate frugivores' guts on germination: a review. Perspectives in Plant Ecology, Evolution and Systematics, 1, 151-190.

Traveset A, Verdú M (2002) A meta-analysis of the effect of gut treatment on seed germination. In: Seed Dispersal and Frugivory: Ecology, Evolution and Conservation (eds Levey DJ, Silva WR, Galetti M), pp. 339-350. CABI Publishing, Wallingford.

Traveset A, Robertson AW, Rodríguez-Pérez J (2007) A review on the role of endozoochory on seed germination. In: Seed Dispersal: Theory and Its Application in a Changing World (ed. Dennis AJ), pp. 78-103. CABI Publishing, Wallingford.

Tsuji Y, Yangozene K, Sakamaki T (2010) Estimation of seed dispersal distance by the bonobo, Pan paniscus, in a tropical forest in Democratic Republic of Congo. Journal of Tropical Ecology, 26, 115-118.

Tutin CEG, Williamson EA, Rogers ME, Fernandez M (1991) A case study of a plant-animal relationship: Cola lizae and lowland gorillas in the Lopé Reserve, Gabon. Journal of Tropical Ecology, 7, 181-199.

Wang BC, Smith TB (2002) Closing the seed dispersal loop. Trends in Ecology and Evolution, 17, 379-386.

Wehncke EV, Dominguez CA (2007) Seed dispersal ecology of non-restricted frugivores, capuchin monkeys in three neotropical forests. Journal of Tropical Ecology, 23, 519-528. 